\title{
Coping with disasters while living in poverty: A systematic review
}

\author{
Revathi N. Krishna ${ }^{a}$ \\ Saadia Majeed ${ }^{\mathrm{a}}$ \\ Kevin Ronan ${ }^{\mathrm{b}}$ \\ Eva Alisic ${ }^{c, d}$
}

\begin{abstract}
${ }^{a}$ Monash University Accident Research Centre, Monash University, VIC, Australia; ${ }^{b}$ School of Human, Health and Social Sciences, Central Queensland University, QLD, Australia; ${ }^{\mathrm{c}}$ Trauma Recovery Lab, Monash University Accident Research Centre, Monash University, VIC, Australia; ${ }^{d}$ Department of Psychosomatics and Psychiatry, University Children's Hospital Zurich, Switzerland.
\end{abstract}

Revathi N. Krishna is a PhD candidate at Monash University Accident Research Centre (MUARC), Monash University. Her PhD research focuses on developing an education based Disaster Risk Reduction intervention for children through active participation of children in flood affected communities in Chennai, India.

Dr. Saadia Majeed is a Research Fellow in Disaster Risk Management, Monash University Disaster Resilience Initiative at Monash University Accident Research Centre. She is also a research scholar affiliated with the International Social Science Council (ISSC) and Integrated Research on Disaster Risk (IRDR) Young Scientists Programme. Currently, she is working on developing an integrated governance approach to disaster risk management which will be especially applicable in developing countries, but which will have a potential for wider application in other disaster-prone regions.

Prof. Kevin Ronan is a Professorial Research Fellow in Clinical Psychology, School of Health, Medical and Applied Sciences at CQUniversity Australia. He is also Chair of the Disaster Reference Group of the Australian Psychological Society.

Dr Eva Alisic leads the Trauma Recovery Lab at Monash University Accident Research Centre. She studies how children, young people, and families cope with traumatic experiences such as war and disaster, and how professionals can support them.

Correspondence concerning this paper should be addressed to Revathi N. Krishna at Monash University Accident Research Centre: 21 Alliance Lane, Monash University, VIC 3800, Australia. Telephone: +61 (03) 9905 4371. Email:

revathi.nuggehallikrishna@monash.edu 


\section{Abstract:}

This review synthesizes the literature on how Asia-Pacific children and families living in poverty cope with disasters. A systematic search yielded 26 studies from six low and middle income countries in the region. Findings emphasized the role of socio-economic factors, socio-cultural factors, and indigenous knowledge. Coping strategies related to finances were most prominently described in the studies, in contrast to health and psychosocial strategies. Substantial gender issues were identified. The review highlights gaps regarding child involvement in research and coping strategies used by children living in poverty.

Keywords: Children, Families, South Asia, LMIC 


\section{Coping with disasters while living in poverty in Asia Pacific: Systematic review}

The Intergovernmental Panel on Climate Change (IPCC) defines disaster as 'Severe alterations in the normal functioning of a community or a society due to hazardous physical events interacting with vulnerable social conditions, leading to widespread adverse human, material, economic, or environmental effects that require immediate emergency response to satisfy critical human needs and that may require external support for recovery' (IPCC, 2012; p. 5). Disasters have a disproportionately adverse effect on low and middle income countries (LMICs) compared to high income countries (HICs). In 2015 alone, the Asia Pacific region experienced about $47 \%$ of the world's disasters with over 16,000 fatalities and over 70 million people affected (Emergency Events Database; EM-DAT, 2016). Consequently, this region, which includes a significant proportion of LMICs, is the world's most disaster prone region (United Nations Economic and Social Commission for Asia and the Pacific, 2015).

Vulnerability to disasters depends on many factors - economic, social, cultural, political, and psychological -- that affect people's susceptibility to environmental hazards in addition to enhanced risk for physical exposure to hazards themselves (Twigg, 2015; Wisner, Blaikie, Cannon, \& Davis, 2004). Although vulnerability is most certainly not exclusively about poverty, it plays a central role in creating and sustaining vulnerability (Akter, \& Mallick, 2013). People living in poverty are particularly vulnerable to the effects of disasters, with long-term economic, health, and mental health consequences (Dercon, 2004; Carter, Peter, Tewodaj, \& Workneh, 2007; Galea, Tracy, Norris, \& Coffey, 2008). While they are more likely to perceive an event as hazardous, people in poverty are less likely to prepare for disasters or evacuate (Fothergill \& Peek, 2004). When disaster strikes, they are at higher risk for physical injuries, mental health problems (Fothergill \& Peek, 2004), and the loss of lives and possessions (Gladwin and Peacock, 1997). Poverty is commonly defined as "an indicator of lack of access to resources and income opportunities" (Yodmani, 2001). It has multiple dimensions, with dependency, lack of power, and lack of voice as central issues (Narayan, Patel, Schafft, Rademacher, \& Koch-Schulte, 1999). Stigma and shame associated with poverty can make it even harder for people in poverty to access resources and services (Patel, \& Kleinman, 2003).

The United Nations Development Programme (UNDP) defines poverty in absolute terms - an income of less than US $\$ 2$ a day. However, the reality of poverty exists on a relative scale, and its definition and measurement are hotly debated (UNDP, 2006). Reducing food intake and withdrawing children from school are examples of how families in poverty may cope with adversities despite the detrimental effect of these strategies (Roncoli, Ingram, $\&$ Kirshen, 2001). People whose lives are not constrained by poverty do not have to engage in similar actions, providing them with better chances of absorbing and coping with current and future adversities (Levine, Ludi, \& Jones, 2011).

Coping capacity is defined as 'the ability of people, organizations and systems, using available skills and resources, to face and manage adverse conditions, emergencies or disasters' (UNISDR, 2009). This is not only confined to individuals' actions, it can be interpreted as a collective effort to address a stressful condition. Conservation of Resources (COR) theory (Hobfoll, 1989) emphasizes that individuals endeavour to obtain, retain and protect the things they value most. Resources include objects (e.g. car, house, other assets), condition resources (social relationships, employment), personal resources (e.g. self-esteem, self-efficacy), and energy resources (e.g. knowledge, money). COR theory postulates that resource loss has more impact than resource gain, and resource loss begets future resource loss. Consequently, loss cycles are more accelerated than gain cycles, helping to explain why people who are socially or economically disadvantaged are more adversely affected by 
disasters. Age, gender, educational level, social support, income level, additional life stressors further influence coping capacity within individuals and collectives (Bonanno, Galea, Bucciarelli \& Vlahov, 2007; Brewin, Andrews, \& Valentine, 2000). Given this context, 'coping' in the current review includes strategies that families employ to ensure physical and mental wellbeing of themselves and their family members.

Children exposed to disasters can be particularly vulnerable and have different needs from adults due to many factors including their age (Peek, 2008), loss of perceived safety, difficulty in making sense of the world, and loss of important attachment figures (Norris, Friedman, \& Watson, 2002). Involving children in disaster risk reduction dialogue has been challenging (UNICEF, 2011, Mudavanhu, et al., 2015), owing to factors related to culture, political will, and motivation of families (Muzenda-Mudavanhu, 2016). At the same time, a number of studies have documented that children themselves are motivated to be part of disaster risk reduction dialogue and related decision-making and action (e.g., see review by Johnson et al., 2014; see also Webb \& Ronan, 2014). Hence, with the recent Sendai Framework (UNISDR, 2015) also highlighting children as "agents of change", it is important to gain insight into how children and families cope with disasters, particularly when it is made more complex through poverty.

With an intent to provide a stepping stone for the development of disaster resilience interventions for children and families living in poverty, the current review aims to answer three questions:

a. How do children and families living in poverty in the Asia Pacific region cope with disasters?

b. What coping strategies have been identified as supporting their psychosocial wellbeing?

c. To what extent have children been actively involved in the studies addressing the first two questions?

\section{Methods}

\section{Search Strategy}

We created a search strategy that covered the major databases linked closely to the fields of disaster, trauma, social sciences and health - CINAHL, MEDLINE, PsycINFO, EMBASE, PILOTS, Proquest and Scopus. We scoped literature relevant to disasters and included MeSH subject headings where applicable. Titles, key terms related to our inclusion criteria, and abstracts from key papers were used to ensure efficiency of the search strategy that would lead to maximum relevant articles. The final search terms to find the studies have been included in the appendices (Appendix 1).

\section{Study Selection}

The articles retrieved via the search strategy were imported into EndNote and duplicates were removed. We excluded grey literature/ non-empirical literature such as conference papers, dissertations, book chapters and reports. We also excluded studies in other languages than English and studies that did not consider psychosocial aspects of coping (e.g. an exclusive focus on agriculture strategies). Two independent researchers (RNK and SM) screened the publications using the title and abstract of 10 articles according to the inclusion/ exclusion criteria (Appendix 2) and reviewed the selection together. The rest of the articles were divided among the two researchers to screen independently, with about $10 \%(n=124)$ of randomly selected articles being screened by both to ensure consensus of screening, with an agreement of over $83 \%$. Based on this finding, we used a conservative approach, retaining papers for full text review in case of any uncertainty rather than excluding them at this stage. 
Full text of these 'selected' ( $\mathrm{n}=204)$ articles were then used to do a final round of selection according to the inclusion/ exclusion criteria. The researchers completed this review independently, then randomly selected about $10 \%(\mathrm{n}=20)$ and achieved a $90 \%$ consensus rate. In order to ensure that no potentially relevant papers were missed, references of the selected articles were reviewed and relevant articles were screened and included if appropriate. The PRISMA flowchart (Fig. 1) details the entire selection process.

\section{<<insert Fig.1: PRISMA-P flowchart of search results〉>}

We assessed each study's quality by using the Mixed Methods Appraisal Tool (MMAT) - Version 2011. The MMAT is adaptable to different methodologies - qualitative, quantitative, and mixed methods with an intraclass correlation of 0.72 to 0.94 (Pace et al., 2012). We developed and piloted a data extraction form based on the principles laid out by Saldana (2013). We categorised the coping strategies using the circle of capacities (Wisner, Gaillard, \& Kelman, 2012) as a starting point. A core concept of the circle of capacities is that no one is completely helpless, but all have certain resources and access to resources that help them cope and recover. The resources included in the circle of capacities are social, human, physical, natural, political and economic resources. Hobfoll, et al., 2007 propose five essential psychological and social elements that aid successful recovery from an adverse event such as a disaster: a sense of safety, calmness, self and collective-efficacy, connectedness and hope. In line with these elements and the Conservation of Resources theory, the resources or coping strategies most relevant to the review relate to human, social and economic resources at the family level. Hence, the categories focused on those strategies that influence the health and wellbeing of children and families - psychosocial strategies, economic strategies, and community based strategies.

\section{Results}

Twenty six studies met the inclusion criteria. These studies described household / families' coping strategies during and after a disaster event in the Asia Pacific region. The methodological rigor of the papers included in the review was average. While $30 \%$ of the studies $(n=8)$ met $75 \%$, and $19 \%(n=5)$ met a full $100 \%$ of the MMAT criteria for their respective methodologies, $50 \%$ of the studies met $50 \%$ or less of the MMAT criteria. Many of these studies did not discuss the potential effects their own researchers' interactions had on their participants and, consequently, on the results of the studies.

The most commonly discussed disaster was related to hydrological events - floods $(n=9)$, cyclones $(n=6)$ and tsunami $(n=2)$. All 26 studies were conducted in LMIC's with a majority of the studies from Bangladesh $(n=10)$ and India $(n=8)$. All studies in the review studied coping mechanisms used by people who lived in poverty - e.g. squatter settlements, slums or similar. Only two studies included children as participants in their studies. A summary of the reviewed studies and the results of the critical review (MMAT score) is presented in Table 1.

$$
\text { <<insert here: Table 1: Summary of the selected papers>> }
$$

\section{Economic coping strategies}

Despite poverty, families tended to prepare for disasters: about $50 \%$ of the families in one study saved regularly with savings groups or NGOs, with the intention of being able to use it after a disaster (Jabeen, Johnson \& Allen, 2011). All the included studies identified borrowing or saving money ahead of time as a coping strategy. Sources from which to borrow money included relatives, friends, past savings, informal credit, or moneylenders and by accessing programs by NGOs. However, this increased debt while income decreased (Mishra, 2007). 
In flood and cyclone related studies, families preferred to stay in their houses in attics or by building barriers using sandbags, or positioning their belongings on stilts, and creating outlets for flow of water, fearing theft of their possessions. Hence, it is not surprising that some studies $(\mathrm{n}=5)$ identified migration as a last resort and usually temporary.

Diversification of income was a common strategy (Mishra, 2007; Matin \& Taylor, 2015; Parida, 2015; Ray-Bennett, 2009). This was done by pursuing other sources of income not normally engaged in. for example collecting recyclable material to sell, laundry, sewing, selling of homemade things. Some families also engaged their children in livelihood activities and pawned their belongings for money (e.g. jewellery, land). Though not common, some studies found that families engaged in begging to cope with the financial burden $(n=5)$. Sometimes, men of these families had to migrate to find work and leave their families behind in order to earn money (Braun \& Aßheuer, 2011; Gaillard, Pangilinan, Cadag, \& Le Masson, 2008; Jülich, 2011; Mallick \& Vogt, 2012), however, this was fraught with its own challenges (e.g., difficulty in finding jobs, no communication with their families, some men abandoned their families and remarried, leaving their wives to fend for themselves and their children).

Some families who had access to resources purchased land on higher ground. Families who were educated (at graduate level) built houses with better materials that in many cases outlasted the disaster event (Mallick, Rahaman, \& Vogt, 2011) and coped better (Matin \& Taylor, 2015).

\section{Health related coping strategies}

All studies indicated that families prepared for disasters by storing food - grains, cereals, dried and powdered green leafy vegetables. In order to get potable water or relief materials, families often travelled considerable distances. Furthermore, all studies reported that families reduced their food intake - usually starting with adults and then if necessary this extended to children and lasted throughout the disaster (Ray-Bennett, et al., 2016). While relief camps during floods provided nutritional support, these were often considered unsuitable for women and children, for instance if toilets in these camps were out in the open (Rashid, 2000). People coped in such situations by walking long distances, including wading in water, to get toileting access. On the other hand, in flood situations, families who remained in their houses found it impossible to access toilets and many times defecated and urinated in the house (Rashid, 2000). Lastly, if a family member, including children, fell sick the usual treatment was to just 'rest' since a doctor was neither affordable nor accessible (Ray-Bennett et al., 2016; Zoleta-Nantes, 2002).

\section{Psychosocial coping strategies}

Families reported that relatives were a source of emotional support. Some studies found that when families were compelled to migrate, more than $50 \%$ of the migration happened into neighbourhoods where friends and families were already present, or that they migrated together (Jabeen, et al., 2011; Rashid, 2000). Families shared services (e.g. toilets) and food with neighbours. Coping strategies also included working together as part of a family and community. For example, neighbours helped each other to build huts or pick up things after the floods from the rivers (Rashid, 2000). Some families got together and mobilized community action (Ray-Bennett et al., 2016). For example, two families bought a boat together and used it to save themselves and their possessions, later renting it out for community use. Cultural practices and the evolution of culture to accommodate the needs of the community after tsunami were instrumental for people in the Samoa islands (Binder, Baker, Mayer, \& O’Donnell, 2014). 


\section{Community based coping strategies}

Indigenous knowledge was recognized as a contributing factor in psychological preparedness towards a disaster (Paul, \& Routray, 2011). Studies $(n=14)$ noted that praying and other religious activities were commonly observed coping strategies. In order to appease the gods, families and communities performed religious rituals and also believed in superstitions which contributed to their preparedness for the disaster (Mishra, 2007). Some communities used rituals to help families grieve. Fishermen in India who lost their children to tsunami remembered them by embracing a tradition: they planted and cared for coconut saplings, they routinely offered their deceased children's favourite food and sat beneath the shadow of the saplings (Rajkumar, Premkumar, \& Tharyan, 2008).

\section{Gender differences in coping with disasters}

Women and girl children were the first family members to reduce their food intake (Parida, 2015; Ray-Bennett et al., 2016), both in the number of times they ate as well as the quantity of food they consumed. Women faced multiple challenges and discrimination; for example domestic violence, or for using relief shelters with other men of the community or lack of legal rights to land (Alam \& Collins, 2010; Mallick, et al., 2011; Mallick \& Vogt, 2012; Matin \& Taylor, 2015; Mishra, 2007; Parida, 2015; Rashid, 2000; Ray-Bennett, 2009). On the other hand, one study reported a reduction in domestic violence and dowry practices after the tsunami (Rajkumar, et al., 2008). Some studies highlighted women's resilience to help themselves and their communities (Binder et al., 2014; Matin \& Taylor, 2015). Other studies found women were more at risk of being exploited (including sexually) on the basis of their religion or social standing in order to receive aid material (Mallick \& Vogt, 2012; Mishra, 2007).

\section{Barriers to coping}

As demonstrated, finances were a source of great stress for families coping with disasters. Migrants, religious minorities or those who were not involved in community organisations found it difficult to access services and relief materials (Chatterjee, 2012; Mallick \& Vogt, 2012; Parida, 2015; Usamah, Handmer, Mitchell, \& Ahmed, 2014). Women and girls were at a higher risk for exploitation (Alam \& Collins, 2010; Mallick, et al., 2011; Matin \& Taylor, 2015; Mishra, 2007; Parida, 2015). Shame and stigma towards disability, homelessness, or seeking support multiple times made accessing services more challenging (Rashid, 2007). Some studies highlighted that the lack education $(n=3)$, thus the lack of awareness and information led to an increase in the families' inability to cope. The presence of multiple agencies (local, national and international), each with their unique and often unaligned objectives presented a challenge for implementation, including of evidence based disaster management practices (Lee, 2016). Corruption and unfair practices were other barriers recognized in some of the studies (Mallick, et al., 2011; Mallick \& Vogt, 2012; Parida, 2015; Usamah et al., 2014).

\section{Attitudes towards disasters and coping}

While most studies did not discuss the attitudes of participants towards disasters, of those who did, a common view was that the events were god's will $(\mathrm{n}=4)$ (e.g. Wisner, et al., 2004; pp. 10). Studies found that participants reported a greater appreciation for life (Wang, Chan, Shi, \& Wang, 2013) or that they took their lives more seriously (Rajkumar, et al., 2008).

\section{Recommendations to aid better coping of families}

Valuing and incorporating indigenous knowledge was recognized as essential in the efforts of both government and civil society (Jabeen, et al., 2010). Both evidence and practice need to be contextualized to the local setting with all members of the community involved 
throughout the disaster cycle (Lee, 2016). A few studies recommended that governments be more cognizant of the factors that create increased vulnerability in order to create programs tackling those issues directly, for e.g., awareness about disasters, better warning systems, education, access to services (Mallick et al., 2011; Mazumdar, Mazumdar, Kanjilal, \& Singh, 2014).

\section{Discussion}

This review highlights the efforts of families to cope with disasters in the Asia Pacific region. The review emphasises the role that socio-economic, socio-cultural factors, and indigenous knowledge play. Health and financial status of a family plays a crucial role, impacting significantly on their ability to cope with and recover from a disaster. Particularly when a family is coping with poverty conditions, this, significantly adds to and entrenches another layer of complexity.

One of the most striking observations that this review brings to the forefront is the woeful lack of information on the perspectives of children and youth. Only three studies included children among their participants. Of them, only one study (Zoleta-Nantes, 2002) captured some of the experiences and challenges that children faced during and in the aftermath of disasters, yet only nine children were part of the study while the rest of the participants $(n=78)$ were adults living in wealthy and poor neighbourhoods.

Finances were a fundamental source of stress for families across studies examined in this review. The review found that families engaged in a plethora of activities to cope with the financial burden of a disaster ranging from saving money or construction material ahead of time to children having to drop out of school in order to contribute to the family's income. Children dropping out of school to earn income is not uncommon, particularly in low and middle income countries such as those included in this review, and considering the financial burden that such unexpected shocks put on families who are already burdened (Alston, 2007; Guarcello, Mealli, \& Rosati, 2009). Borrowing money as a result of, or in preparation for the hazard, was observed in all studies. Additional findings indicated that borrowing exacerbated family debt levels and increased the risk of additional exploitation via labour or even loss of land. The review also highlighted the difficulties members of minority groups, and women, had in receiving relief materials. Women and girls are especially vulnerable to exploitation and domestic violence in these situations (Jones-DeWeever, 2007; Chew \& Ramdas, 2005; WHO, 2002). Stigma, shame, corruption and unfair practices (e.g. discrimination by aid providers) created further barriers. In general, families didn't want to continually access such available resources, especially financial support due to stigma related to receiving that support or for the fear of increased debt making their already financial hard life even more difficult. This set of circumstances can be seen through the lens of "secondary stressors". Secondary stressors are those factors that arise following a disaster that confer additional coping stress and are a known major risk, and complicating factor after disasters (Norris et al., 2002).

Families found that social bonds, social solidarity and community activities assisted them to cope with disasters. The role of social and community support is of course supported, and robustly so, by much research (McFarlane, 1987; Norris et al., 2002, 2008). Not surprisingly, families that had higher education levels coped better as they tended to be able to save money more readily, knew to watch for signs of and prepare for disasters, and were 
able to afford better building materials and other resources, highlighting the importance of the role of education in reducing disaster risk.

\section{Limitations}

This review includes a small set of studies and all are from LMICs, hence, the study is not representative of the Asia Pacific region. Additionally, hydrological events were dominant in the selected studies; our search strategy included all types of hazards but none of the studies about non-hydrological events fitted our inclusion criteria. The review is also limited due selecting only publications written in English. Finally, the review excluded the grey literature and hence might have missed potential coping strategies discussed in reports by community organisations who form an integral part of disaster response and recovery.

\section{Future directions}

There is growing evidence of the advantages of including children as active participants in disaster risk reduction (DRR; Ronan, Crellin, \& Johnston, 2010; Ronan \& Johnston, 2005; Wachtendorf, Brown, \& Nickle, 2008), response and recovery dialogue. Despite these efforts, this review shows how little their voices are heard. Further childcentered research focusing those who live in complex situations like poverty, institutional care, or in other non-traditional family contexts is a priority.

\section{Conclusion}

The systematic review details the coping strategies that are employed by families living in poverty and subject to disaster experiences. The review showed that people living in poverty can be resourceful and prepared to fortify themselves against such crises. Indigenous knowledge, culture and social bonding appear to play a key role in coping. Families use different strategies throughout the cycle of disaster in order to protect themselves not only from physical hazards, but also from the economic burdens that can accompany disasters. On the other hand, families face fundamental challenges at various levels from individual (e.g. lack of education) to systemic (e.g. lack of access to free medical services or relief after a disaster). Common issues include finances, housing and hygiene and sanitation, typically discussed in the studies in some detail. By contrast, there is a critical gap in consideration, and inclusion of, children's needs in this complex combination of poverty and disasters. This includes issues linked to major rights of children, including protection, participation and equity (UN Convention on the Rights of the Child, 1989). Additionally, a focus on mental health and wellbeing issues in the included studies was also lacking. Women and girls are not only vulnerable to the risks of disasters, but also to exploitation and discrimination. Finally, the results make it clear that families' socio-economic status is a major driver of coping strategies and ultimate coping success, including such issues as whether they had to reduce their food intake, or whether their children had to drop out of school to contribute to the household income. 


\section{References}

Akter, S., Mallick, B. (2013). The poverty-vulnerability-resilience nexus: Evidence from Bangladesh. Ecological Economics, 96, 114-124. Retrieved from: http://dx.doi.org/10.1016/j.ecolecon.2013.10.008

Alam, E. and A. E. Collins. (2010). Cyclone disaster vulnerability and response experiences in coastal Bangladesh. Disasters, 34(4), 931-954. DOI: 10.1111/j.14677717.2010.01176.x

Alston, M. (2007). It's really not easy to get help: Services to drought-affected families. Australian Social Work, 60(4), 421-435. Retrieved from: http://dx.doi.org/10.1080/03124070701671149

Bhandari, R. B., Okada, N., Knottnerus, J. D. (2011). Urban ritual events and coping with disaster risk a case study of Lalitpur, Nepal. Journal of Applied Social Science, 5(2), 13-32. Retrieved from http://www.jstor.org/stable/23548972

Binder, S. B., Baker, C. K., Mayer, J., \& O’Donnell, C. R. (2014). Resilience and recovery in American Sāmoa: A case study of the 2009 south pacific tsunami. Journal of Community Psychology, 42(7), 799-822. DOI: 10.1002/jcop.21654

Bonanno, G. A., Galea, S., Bucciareilli, A., \& Vlahov, D. (2007). What predicts psychological resilience after Disaster? The role of Demographics, Resources and Life Stress. Journal of Consulting and Clinical Psychology, 75(5), 671 - 682. DOI: DOI: 10.1037/0022-006X.75.5.671

Braun, B. and T. Aßheuer (2011). Floods in megacity environments: Vulnerability and coping strategies of slum dwellers in Dhaka/Bangladesh. Natural Hazards, 58(2), 771-787. DOI: 10.1007/s11069-011-9752-5

Brewin, C. R., Andrews, B., \& Valentine, J. D. (2000). Meta-analysis of risk factors for posttraumatic stress disorder in trauma-exposed adults. Journal of Consulting and Clinical Psychology. 68(5), 748 -766. DOI: 10.1037//0022-006X.68.5.748

Carter, M., Peter, L., Tewodaj, M., \& Workneh, N. (2007). Poverty traps and natural disasters in Ethiopia and Honduras. World Development, 35(5), 835-856.

Chambers, R. (2002). Power, knowledge and policy influence: reflections on an experience. In Knowing Poverty: Critical reflections on participatory research and policy. Karen Brock and Rosemary McGee (eds), London.

Chatterjee, M. (2010). Slum dwellers response to flooding events in the megacities of India. Mitigation and Adaptation Strategies for Global Change, 15(4), 337-353. DOI: 10.1007/s11027-010-9221-6

Chew, L. \& Ramdas, K. N. (2005). Caught in the Storm: Impact of Natural Disasters on Women. Global Fund for Women: San Francisco.

Dercon, S. (2004). Growth and shocks: evidence from rural Ethiopia. Journal of Development Economics, 74, 309-329. Retrieved from: https://doi.org/10.1016/j.jdeveco.2004.01.001

Edward, P. (2006). The Ethical Poverty Line: a moral quantification of absolute poverty. Third World Quarterly, 27(2). 
EM-DAT. (2016). The OFDA/CRED International Disaster Database. Available at http://www.emdat.be (Accessed 16 July 2016).

ESCAP. (2015). Disasters in Asia and the Pacific: 2015 Year in Review. Available at http://www.unescap.org/resources/disasters-asia-and-pacific-2015-yearreview (Accessed 2 July 2016).

Fothergill, A., and Peek. L. A., (2004). Poverty and Disasters in the United States: A Review of Recent Sociological Findings. Natural Hazards, 32, 89-110. DOI: 10.1023/B:NHAZ.0000026792.76181.d9

Gaillard, J. C., Pangilinan, M., Cadag, J. R., \& Le Masson, V. (2008). Living with increasing floods: Insights from a rural Philippine community. Disaster Prevention and Management, 17(3), 383-395. DOI: 10.1108/09653560810887301

Galea, S., Nandi, A., \& Vlavhov, D. (2005). The Epidemiology of PTSD after Disasters. Epidemiologic reviews, 27(1), 78-91. DOI:10.1093/epirev/mxi003.

Galea, S., Tracy, M., Norris, F., \& Coffey, S.F. (2008). Financial and social circumstances and the incidence and course of PTSD in Mississippi during the first two years after Hurricane Katrina. Journal of Traumatic Stress, 21(4), 357-68. DOI: $10.1002 /$ jts. 20355

Gladwin, H., \& Peacock, W. G. (1997). Warning and Evacuation: A Night of Hard Choices. In Hurricane Andrew: Ethnicity, Gender and the Sociology of Disasters. New York: Routledge

Guarcello, L., Mealli, F., \& Rosati, F. C. (2009). Household vulnerability and child labour: the effect of shocks, credit rationing, and insurance. Journal of Population Economics, 23(1), 169-198. DOI: 10.1007/s00148-008-0233-4.

Hobfoll S. E, Watson P, Bell C. C, Bryant R. A, Brymer M. J, Friedman M. J, et al. (2007). Five essential elements of immediate and mid-term mass trauma intervention: Empirical evidence. Psychiatry. 70, 283-315. DOI: 10.1521/psyc.2007.70.4.283

Hobfoll, S. E. (1989). Conservation of resources: A new attempt at conceptualizing stress. American Psychologist, 44(3), 513- 524.

Jabeen, H., Johnson, C., \& Allen, A. (2010). Built-in resilience: Learning from grassroots coping strategies for climate variability. Environment and Urbanization, 22(2), 415431. DOI: $10.1177 / 0956247810379937$.

Johnson, V. A., Johnston, D. M., Ronan, K. R., \& Peace, R. (2014). Evaluating children's learning of adaptive response capacities from ShakeOut, an earthquake and tsunami drill in two Washington State school districts. Journal of Homeland Security and Emergency Management, 11(3), 1-27. DOI: 10.1515/jhsem-2014-0012.

Jones-DeWeever, A. (2007). Women in the Wake of the Storm: Examining the Post-Katrina Realities of the Women of New Orleans and the Gulf Coast Executive Summary. Institute for Women's Policy Research: Washington, DC.

Jülich, S. (2011). Drought Triggered Temporary Migration in an East Indian Village. International Migration, 49(1), 189-199. DOI: 10.1111/j.1468-2435.2010.00655.x.

Lee, A. C. K. (2016). Barriers to evidence-based disaster management in Nepal: A qualitative study. Public Health, 133, 99-106. DOI: 10.1016/j.puhe.2016.01.007. 
Levine, S., Ludi, E., \& Jones, L. (2011). Rethinking support for adaptive capacity to climate change - the role of development interventions: A report for the Africa Climate Change Resilience Alliance. Overseas Development Institute: London.

Mallick, B., Rahaman, K. R., \& Vogt, J. (2011). Social vulnerability analysis for sustainable disaster mitigation planning in coastal Bangladesh. Disaster Prevention and Management, 20(3), 220-237. Retrieved from: http://dx.doi.org/10.1108/09653561111141682

Matin, N., \& Taylor, R. (2015). Emergence of human resilience in coastal ecosystems under environmental change. Ecology and Society, 20(2), 43. DOI: 10.5751/ES-07321200243.

Mazumdar, S., Mazumdar, P. G., Kanjilal, B., \& Singh, P. K. (2014). Multiple shocks, coping and welfare consequences: Natural disasters and health shocks in the Indian Sundarbans. PLoS ONE, 9(8): e105427. Retrieved from: https://doi.org/10.1371/journal.pone.0105427

McFarlane, A. C. (1987). Family Functioning and Overprotection Following a Natural Disaster: The Longitudinal Effects of Post-Traumatic Morbidity. Australian and New Zealand Journal of Psychiatry, 21(2), 210-218.

Mishra, S. (2007). Household livelihood and coping mechanism during drought among Oraon tribe of Sundargarh district of Orissa, India. Journal of Social Sciences, 15(2), 181186.

Mudavanhu, C., Manyena, S.B., Collins, A.E., Bongo, P., Mavhura, E., \& Manatsa, D. (2015). International Journal of Disaster Risk Science, 6(3), 267-281. DOI:10.1007/s13753-015-0060-7

Muzenda-Mudavanhu, C. (2015). A review of children's participation in disaster risk reduction. Jàmbá: Journal of Disaster Risk Studies, Available at: <http://www.jamba.org.za/index.php/jamba/article/view/218/428>. Date accessed: 25 Aug. 2016.

Narayan, D., Patel, R., Schafft, K., Rademacher, A., \& Koch-Schulte, S. (1999). Can Anyone Hear Us? Voices from 47 Countries. Poverty Group, PREM, World Bank.

Norris, F. H., Friedman, M. J., Watson, P. J. (2002). 60,000 Disaster Victims Speak: Part I. An Empirical Review of the Empirical Literature, 1981 - 2001. Psychiatry, 65(3), 207-239. Retrieved from: https://doi.org/10.1521/psyc.65.3.207.20173

Norris, F. H., Stevens, S. P., Pfefferbaum, B., Wyche, K. F., \& Pfefferbaum, R. L. (2008). Community resilience as a metaphor, theory, set of capacities, and strategy for disaster readiness. American Journal of Community Psychology, 41(1-2), 127-150. DOI: $10.1007 / \mathrm{s} 10464-007-9156-6$

Pace, R., Pluye, P., Bartlett, G., Macaulay, A., Salsberg, J., Agosh, J., \& Seller, R. (2012). Testing the reliability and efficiency of the pilot Mixed Methods Appraisal Tool (MMAT) for systematic mixed studies review. International Journal of Nursing Studies, 49(1), 47. DOI: 10.1016/j.ijnurstu.2011.07.002

Parida, P. K. (2015). Natural Disaster and Women's Mental Health. Social change, 45(2), 256-275. Retrieved from: http://dx.doi.org/10.1177/0049085715574189

Patel, V., Kleinman, A. (2003). Poverty and common mental disorders in developing countries. Bulletin World Health Organisation, 81, 609-15. 
Paul, S. K., \& Routray, J. K. (2011). Household response to cyclone and induced surge in coastal Bangladesh: Coping strategies and explanatory variables. Natural Hazards, 57(2), 477-499. Retrieved from: http://dx.doi.org/10.1007/s11069-010-9631-5.

Peek, L. (2008). Children and Disasters: Understanding Vulnerability, Developing Capacities, and Promoting Resilience - An Introduction. Children, Youth and Environments 18(1), 1-29. Retrieved from: http://www.jstor.org/stable/10.7721/chilyoutenvi.18.1.0001

Pluye, P., Robert, E., Cargo, M., Bartlett, G., O’Cathain, A., Griffiths, F., Boardman, F., Gagnon, M.P., \& Rousseau, M.C. (2011). Proposal: A mixed methods appraisal tool for systematic mixed studies reviews. Department of Family Medicine, McGill University, Montreal, Canada. Retrieved from http://mixedmethodsappraisaltoolpublic.pbworks.com. Archived by WebCite ${ }^{\circledR}$ athttp://www.webcitation.org/5tTRTc9yJ.

Rajkumar, A., Premkumar, T., \& Tharyan, P. (2008). Coping with the Asian tsunami: Perspectives from Tamil Nadu, India on the determinants of resilience in the face of adversity. Social Science \& Medicine, 67(5), 844 - 53. DOI: $\underline{10.1016 / j . s o c s c i m e d .2008 .05 .014}$

Rashid, S. F. (2000). The urban poor in Dhaka City: Their struggles and coping strategies during the floods of 1998. Disasters, 24(3), 240-253. DOI: 10.1111/1467-7717.00145

Ray-Bennett, N. S. (2009). Coping with multiple disasters and diminishing livelihood resources caste, class, and gender perspectives: The case from Orissa, India. Regional Development Dialogue, 30(1), 108-120.

Ray-Bennett, N. S., Collins, A. E., Edgeworth, R., Abbas, B., Papreen, N., \& Fariba, A. (2016). Everyday health security practices as disaster resilience in rural Bangladesh. Development in Practice, 26(2), 170-183.

Ronan, K. R., \& Johnston. D. M. (2005). Promoting community resilience in disasters: The role for schools, youth, and families. New York: Springer. ISBN: 978-0-387-23821-0

Ronan, K. R., Crellin, K. \& Johnston, D. (2010). Correlates of hazards education for youth: a replication study. Natural Hazards, 53(3), 503-526. DOI: 10.1007/s11069-009-94446.

Roncoli, C., Ingram, K., \& Kirshen, P. (2001). The costs and risks of coping with drought: livelihood impacts and farmers responses in Burkina Faso. Climate Research, 19(2), 119-132. DOI: $10.3354 / \mathrm{cr} 019119$

Saldaña, J. (2013). The coding manual for qualitative researchers. SAGE: Los Angeles. $2^{\text {nd }}$ Edition. ISBN-13: 978-1446247372

Sultana, N., \& Rayhan, M. I. (2012). Coping strategies with floods in Bangladesh: An empirical study. Natural Hazards, 64(2), 1209-1218. DOI: 10.1007/s11069-0120291-5

Twigg, J. (2015). Good Practice Review: Disaster Risk Reduction, London: Overseas Development Institute. Retrieved from: http://goodpracticereview.org/wpcontent/uploads/2015/10/GPR-9-web-string-1.pdf

UNISDR (United Nations International Strategy for Disaster Reduction). 2015. Sendai framework for disaster risk reduction 2015-2030. Geneva: UNISDR. 
United Nations. (1989). United Nations convention on the rights of the child. United Nations: Geneva

Usamah, M., Handmer, J., Mitchell, D., \& Ahmed, I. (2014). Can the vulnerable be resilient? Co-existence of vulnerability and disaster resilience: Informal settlements in the Philippines. International Journal of Disaster Risk Reduction, 10(A), 178-189. DOI: 10.1016/j.ijdrr.2014.08.007.

Wachtendorf, T., Brown, B., and Mickle, M. C. (2008). Big Bird, Disaster Masters, and High School Students Taking Charge: The Social Capacities of Children in Disaster Education. Children, Youth and Environments, 18(1), 456-469. Retrieved from: http://www.jstor.org/stable/10.7721/chilyoutenvi.18.issue-1

Wang, X. L., Chan, C. L. W., Shi, Z. B., \& Wang, B. (2013). Mental health risks in the local workforce engaged in disaster relief and reconstruction. Qualitative health research, 23(2), 207-217. DOI: 10.1177/1049732312467706

Wang, X. L., Shi, Z. B., Ng, S. M., Wang, B., \& Chan, C. L. W. (2011). Sustaining engagement through work in post disaster relief and reconstruction. Qualitative health research, 21(4), 465-476. DOI: 10.1177/1049732310386049

Webb, M. \& Ronan, K. R. (2014). Interactive hazards education program in a low SES community: A quasi-experimental pilot study. Risk Analysis, 34(10), 1882-93. DOI: 10.1111/risa.12217

Wisner, B. Gaillard, J. C., \& Kelman, I. (2012). Framing disaster: Theories and stories seeking to understand hazards, vulnerability and risk. In: B. Wisner, JC Gaillard and I. Kelman, eds, The Routledge Handbook of Hazards and Disaster Risk Reduction, pp. 18-34. London: Routledge.

Wisner, B., Blackie, P., Cannon, T. \& Davis, I. (2004) At Risk: Natural Hazards, People's Vulnerability and Disasters. Routledge Publication, London and New York, $2^{\text {nd }}$ edition. ISBN-13: 978-0415252164

World Health Organization. (2003). Department of Gender and Women's Health. Gender and Health in Disasters. Available at: http://www.who.int/gender/other_health/en/genderdisasters.pdf

Yodmani, S. (2001, February). Disaster risk management and vulnerability reduction: protecting the poor. Paper presented at the Asian and Pacific Forum on Poverty, Manila, Philippines.

Zoleta-Nantes, D. B. (2002). Differential Impacts of Flood Hazards among the Street Children, the Urban Poor and Residents of Wealthy Neighbourhoods in Metro Manila, Philippines. Mitigation and Adaptation Strategies for Global Change, 7(3), 239-266. DOI: 10.1023/A:1024471412686

Acknowledgments: We would like to thank the Journal of Loss and Trauma for the opportunity. Ms. Krishna is supported by Monash University International Postgraduate Research Scholarship. Dr Alisic is supported by the Australian National Health and Medical Research Council (Early Career Fellowship 1090229). Both Drs. Alisic and Ronan are supported by Australia's Bushfire and Natural Hazards Cooperative Research Centre.

Conflict of interest: The authors declare that they have no conflict of interest. 
Figure 1: PRISMA-P Flow Chart

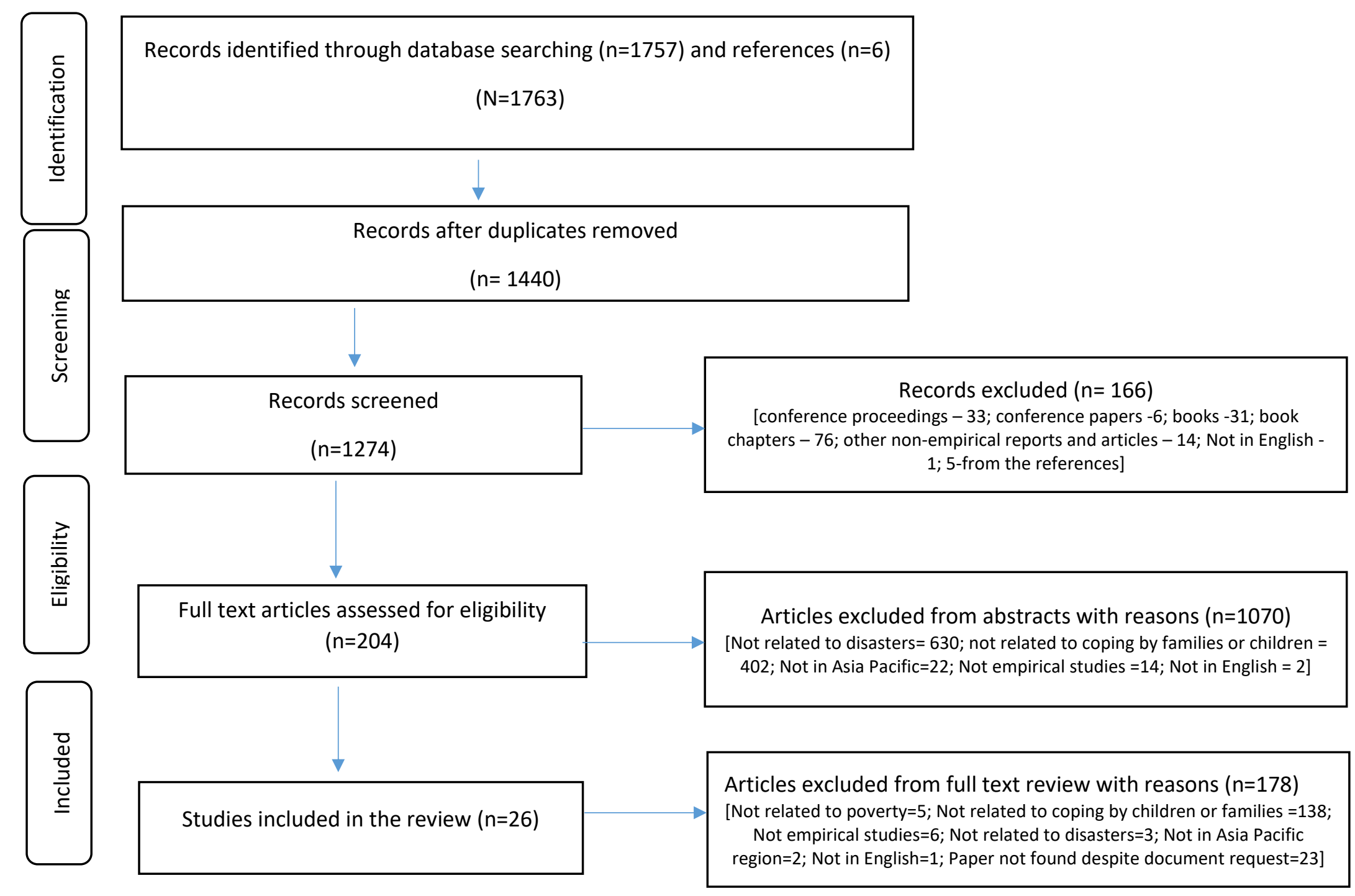


Table 1: Summary of the selected papers

\begin{tabular}{|c|c|c|c|c|}
\hline Author \& date & $\begin{array}{l}\text { Disaster Type and } \\
\text { Location }\end{array}$ & $\begin{array}{l}\text { Study \& Sample } \\
\text { description }\end{array}$ & $\begin{array}{l}\text { MMAT Score* } \\
\text { (Critical } \\
\text { Appraisal of the } \\
\text { Paper) }\end{array}$ & Coping strategies \\
\hline $\begin{array}{l}\text { Alam, \& Collins } \\
\text { (2010) }\end{array}$ & $\begin{array}{l}\text { Cyclone hazards, } \\
\text { Bangladesh }\end{array}$ & $\begin{array}{l}\text { Qualitative study- } \\
\text { combination of } \\
\text { participant observation } \\
\text { and non-participant } \\
\text { external interactions. } \\
\text { Interviews with } 120 \\
\text { (108-male; } 12 \text { - female) } \\
\text { heads of households } \\
\text { and } 8 \text { focus group } \\
\text { discussions with adults }\end{array}$ & QL-2 & $\begin{array}{l}\text { - Use of social support } \\
\text { networks } \\
\text { - Increased religious } \\
\text { activities } \\
\text { - } \text { Raised platforms } \\
\text { - Community initiatives - } \\
\text { e.g. communal cooking }\end{array}$ \\
\hline $\begin{array}{l}\text { Bhandari, et al. } \\
\text { (2011) }\end{array}$ & $\begin{array}{l}\text { Earthquake of 1934; } \\
\text { Nepal }\end{array}$ & $\begin{array}{l}\text { Qualitative study with } \\
15 \text { elderly respondents, } \\
\text { personal observation, } \\
\text { interview with } \\
\text { residents and content } \\
\text { analysis of } \\
\text { ethnographic evidence } \\
\text { from secondary sources }\end{array}$ & QL- 2 & $\begin{array}{l}\text { - Use of religious and } \\
\text { cultural practices } \\
\text { - Use of social support } \\
\text { networks } \\
\text { - Use of indigenous } \\
\text { knowledge }\end{array}$ \\
\hline $\begin{array}{l}\text { Braun, \& } \\
\text { Aßheuer, (2011) }\end{array}$ & $\begin{array}{l}\text { Floods - Dhaka, } \\
\text { Bangladesh }\end{array}$ & $\begin{array}{l}\text { Quantitative }-625 \\
\text { households from } 5 \\
\text { study sites. }\end{array}$ & QT -3 & $\begin{array}{l}\text { - Saving \& borrowing } \\
\text { money } \\
\text { - Store food } \\
\text { - Block entry of water in the } \\
\text { house }\end{array}$ \\
\hline
\end{tabular}




\begin{tabular}{|c|c|c|c|c|}
\hline & & & & $\begin{array}{l}\text { - } \text { Reduction in food } \\
\text { consumption } \\
\text { - Use of social networks }\end{array}$ \\
\hline Binder (2014) & $\begin{array}{l}2009 \text { Tsunami, } \\
\text { Samoa Island }\end{array}$ & $\begin{array}{l}\text { Qualitative study. } n=37 \\
\text { participants via the } \\
\text { project website (9- } \\
\text { male, } 28 \text {-female); } n=29 \\
\text { individual interviews; } 2 \\
\text { FGDs were conducted }\end{array}$ & QL -4 & $\begin{array}{l}\text { - Saving \& borrowing } \\
\text { money } \\
\text { - Support within the } \\
\text { community } \\
\text { - Development of cultural } \\
\text { support networks to } \\
\text { grieve and cope }\end{array}$ \\
\hline Chatterjee (2010) & $\begin{array}{l}\text { Floods of } 2005 \text { in } \\
\text { India }\end{array}$ & $\begin{array}{l}\text { Quantitative study with } \\
50 \text { households from } \\
\text { slums severely affected } \\
\text { by floods in India }\end{array}$ & QT -2 & $\begin{array}{l}\text { - } \quad \text { Borrowing money } \\
\text { - } \text { Storing food } \\
\text { - } \text { Creating elevated } \\
\text { platforms in the house }\end{array}$ \\
\hline $\begin{array}{l}\text { Gaillard et al. } \\
(2008)\end{array}$ & $\begin{array}{l}\text { Floods in Sagrada, } \\
\text { Philippines }\end{array}$ & $\begin{array}{l}\text { Mixed methods; } 20 \text { in } \\
\text { depth interviews, } 46 \\
\text { households surveyed, } \\
\text { and relevant } \\
\text { publications } \\
\text { (newspaper clippings, } \\
\text { journal publications, } \\
\text { similar) }\end{array}$ & MM-3 & $\begin{array}{l}\text { - } \quad \text { Storing of food } \\
\text { - } \text { Reducing food intake } \\
\text { - } \text { Borrow \& save money } \\
\text { - } \text { Migration } \\
\text { - } \quad \text { Dike construction }\end{array}$ \\
\hline $\begin{array}{l}\text { Jabeen et al. } \\
(2010)\end{array}$ & $\begin{array}{l}\text { Floods and heat- } \\
\text { waves, Bangladesh }\end{array}$ & $\begin{array}{l}\text { Qualitative study with } \\
35 \text { households selected } \\
\text { and } N=163 \text { interviews } \\
\text { (36\% aged between } 15 \\
\text { and } 30 \text { years, } 17 \% \text { were } \\
\text { aged } 35 \text { to } 45 \text { years. } \\
\text { Almost } 30 \% \text { were less } \\
\text { than age } 10 .\end{array}$ & QL -2 & $\begin{array}{l}\text { - Saving and borrowing } \\
\text { money } \\
\text { - Sharing services with } \\
\text { neighbours } \\
\text { - Creating barriers to block } \\
\text { flood water from entering } \\
\text { houses }\end{array}$ \\
\hline
\end{tabular}




\begin{tabular}{|c|c|c|c|c|}
\hline Jülich (2011) & $\begin{array}{l}\text { Drought of 2003, } \\
\text { India }\end{array}$ & $\begin{array}{l}\text { Quantitative study with } \\
39 \text { households }\end{array}$ & QT -1 & $\begin{array}{l}\text { - } \text { Reduction in food } \\
\text { consumption } \\
\text { - } \text { Borrow money } \\
\text { - Use of social network - } \\
\text { especially in cases of } \\
\text { migration }\end{array}$ \\
\hline Lee (2016) & $\begin{array}{l}\text { No specific Event, } \\
\text { Nepal }\end{array}$ & $\begin{array}{l}\text { Qualitative study with } \\
11 \text { participants - } \\
\text { government officials, } \\
\text { researchers, inter- } \\
\text { governmental agencies, } \\
\text { and NGOs. }\end{array}$ & QL-1 & $\begin{array}{l}\text { - Use of social support } \\
\text { systems } \\
\text { - Borrow money }\end{array}$ \\
\hline $\begin{array}{l}\text { Mallick \& Vogt } \\
\text { (2012) }\end{array}$ & $\begin{array}{l}\text { Cyclone Aila 2009, } \\
\text { Bangladesh }\end{array}$ & $\begin{array}{l}\text { Mixed methods - field } \\
\text { survey }-\mathrm{N}=288 \\
\text { participants; in-depth } \\
\text { interviews }=\mathrm{N}=280 \\
\text { participants ( } 80 \\
\text { females). Average age } \\
\text { of participants = } \\
\text { 45years }\end{array}$ & MM -2 & $\begin{array}{l}\text { - Borrow money } \\
\text { - Sell possessions } \\
\text { - Use social networks, } \\
\text { especially in cases of } \\
\text { migration }\end{array}$ \\
\hline $\begin{array}{l}\text { Mallick et al. } \\
\text { (2011) }\end{array}$ & $\begin{array}{l}\text { Cyclone Sidr 2007, } \\
\text { Bangladesh }\end{array}$ & $\begin{array}{l}\text { Mixed methods - } \\
\text { survey on } 124 \\
\text { households ( } 110- \\
\text { males,14 were female) } \\
\text { In-depth interviews } \\
\text { conducted with elderly } \\
\text { of the community }\end{array}$ & $\mathrm{MM}-2$ & $\begin{array}{l}\text { - Saved food } \\
\text { - } \quad \text { Borrow and save money } \\
\text { - } \text { Access of relief aid and } \\
\text { available services } \\
\text { - Social support within the } \\
\text { community }\end{array}$ \\
\hline $\begin{array}{l}\text { Matin \& Taylor } \\
(2015)\end{array}$ & $\begin{array}{l}\text { Cyclone Aila 2009, } \\
\text { Bangladesh }\end{array}$ & $\begin{array}{l}\text { Mixed methods - } 43 \\
\text { participants (19- } \\
\text { females, } 24-\text { males) }\end{array}$ & MM-3 & $\begin{array}{l}\text { - Seasonal calendar of } \\
\text { livelihood - diversification }\end{array}$ \\
\hline
\end{tabular}




\begin{tabular}{|c|c|c|c|c|}
\hline & & & & $\begin{array}{l}\text { of income according to } \\
\text { indigenous knowledge. } \\
\text { - Borrow money }\end{array}$ \\
\hline $\begin{array}{l}\text { Mazumdar et al. } \\
\text { (2014) }\end{array}$ & $\begin{array}{l}\text { Cyclone Aila 2009, } \\
\text { India }\end{array}$ & $\begin{array}{l}\text { Quantitative }-180 \\
\text { households }-(N=809)\end{array}$ & QT-3 & $\begin{array}{ll}\text { - } & \text { Borrow money } \\
\text { - } & \text { Reduction in food } \\
\text { consumption } \\
\text { - Use of social support } \\
\text { networks }\end{array}$ \\
\hline Mishra (2007) & Drought 2002, India & $\begin{array}{l}\text { Mixed methods }-\mathrm{N}=40 \\
\text { [ }=20 \text { household } \\
\text { surveys \& } n=20 \text { key } \\
\text { informant data] and } 5 \\
\text { case studies reviewed }\end{array}$ & MM -1 & $\begin{array}{l}\text { - } \text { Borrow money } \\
\text { - Use of social support } \\
\text { - } \text { networks } \\
\text { - } \text { Reducrsification of income } \\
\text { - } \text { consumption food } \\
\text { - Storing food }\end{array}$ \\
\hline Mishra (2012) & Drought, India & $\begin{array}{l}\text { Quantitative - } 257 \\
\text { households }\end{array}$ & QT -2 & $\begin{array}{ll} & \text { Use of social support } \\
\text { networks } \\
\text { - } & \text { Migration } \\
\end{array}$ \\
\hline Parida (2015) & Flood, India & $\begin{array}{l}\text { Qualitative study } \mathrm{N}=68 \\
\text { selected based on their } \\
\text { status, ethnicity and } \\
\text { caste background. Age } \\
20 \text { - } 75 \text { years old. }\end{array}$ & QL-2 & $\begin{array}{ll}\text { - } & \text { Reduced food } \\
\text { consumption } \\
\text { - } & \text { Borrow money } \\
\text { - } & \text { Use of social support } \\
\text { networks } \\
\text { - } & \text { Diversification of income } \\
\end{array}$ \\
\hline $\begin{array}{l}\text { Paul \& Routray } \\
\text { (2011) }\end{array}$ & $\begin{array}{l}\text { Cyclone, } \\
\text { Bangladesh }\end{array}$ & $\begin{array}{l}\text { Mixed methods - } 331 \\
\text { households }\end{array}$ & $\mathrm{MM}-3$ & $\begin{array}{ll}\text { - } & \text { Reduced food } \\
& \text { consumption } \\
\text { - } & \text { Relief aid use } \\
\text { - } & \text { Borrow money } \\
\text { - } & \text { Saving food }\end{array}$ \\
\hline
\end{tabular}




\begin{tabular}{|c|c|c|c|c|}
\hline & & & & $\begin{array}{l}\text { - Use of social support } \\
\text { networks } \\
\text { - Use of indigenous } \\
\text { knowledge }\end{array}$ \\
\hline $\begin{array}{l}\text { Rajkumar et al. } \\
\text { (2008) }\end{array}$ & Tsunami 2004, India & $\begin{array}{l}\text { Qualitative study - } 6 \\
\text { focus group discussions } \\
\text { (FGDs) conducted. } \\
\text { Total N not available }\end{array}$ & QL- 2 & $\begin{array}{l}\text { - } \quad \text { Borrow money } \\
\text { - Use of social support } \\
\text { networks } \\
\text { - Use of cultural practices }\end{array}$ \\
\hline Rashid (2000) & Flood, Bangladesh & $\begin{array}{l}\text { Qualitative study - } \\
\text { Participants were } \\
\text { selected from } 5 \text { slums } \\
\text { in Dhaka city. } N=32 \text { ( } 20 \\
\text { women and } 12 \text { men) }\end{array}$ & QL-3 & $\begin{array}{ll}\text { - } & \text { Use of social support } \\
\text { networks } \\
\text { - } & \text { Borrow and save money } \\
\text { - } & \text { Raised platforms at home } \\
& \text { to save possessions }\end{array}$ \\
\hline $\begin{array}{l}\text { Ray- Bennett } \\
(2009)\end{array}$ & $\begin{array}{l}\text { No specific disaster, } \\
\text { India }\end{array}$ & $\begin{array}{l}\text { Qualitative study. } \mathrm{N}= \\
32 \text { [12 governmental } \\
\text { and non governmental } \\
\text { organizations (NGOs) } \\
\text { and } 12 \text { widowed } \\
\text { women] }\end{array}$ & $\mathrm{QL}-3$ & $\begin{array}{l}\text { - } \text { Reduction in food } \\
\text { consumption } \\
\text { - Use of social support } \\
\text { networks } \\
\text { - } \quad \text { Storing of food } \\
\text { - } \quad \text { Diversification of income }\end{array}$ \\
\hline $\begin{array}{l}\text { Ray- Bennett et al. } \\
(2016)\end{array}$ & $\begin{array}{l}\text { Flood 2008, } \\
\text { Bangladesh }\end{array}$ & $\begin{array}{l}\text { Qualitative study with } \\
10 \text { households [5 male } \\
\text { and } 5 \text { female headed } \\
\text { households] }\end{array}$ & $\mathrm{QL}-1$ & $\begin{array}{l}\text { - } \quad \text { Storing of food } \\
\text { - } \quad \text { Use of social support } \\
\text { networks } \\
\text { - } \quad \text { Community mobilisation }\end{array}$ \\
\hline Sultana (2012) & $\begin{array}{l}2005 \text { Flood, } \\
\text { Bangladesh }\end{array}$ & $\begin{array}{l}\text { Quantitative method- } \\
\mathrm{N}=595 \text { households }\end{array}$ & QT - 3 & $\begin{array}{l}\text { - } \text { Reduced food } \\
\text { consumption } \\
\text { - } \text { Borrow money } \\
\text { - Use of relief aid }\end{array}$ \\
\hline
\end{tabular}




\begin{tabular}{|c|c|c|c|c|}
\hline $\begin{array}{l}\text { Usamah et al. } \\
\text { (2014) }\end{array}$ & $\begin{array}{l}\text { Volcano, two } \\
\text { barangays in } \\
\text { Philippines }\end{array}$ & $\begin{array}{l}\text { Mixed methods case } \\
\text { study }-\mathrm{N}=100\end{array}$ & MM 2 & $\begin{array}{l}\text { - Use of social support } \\
\text { networks } \\
\text { - } \quad \text { Borrow money } \\
\text { - Use of cultural values }\end{array}$ \\
\hline Wang et al. (2013) & $\begin{array}{l}2008 \text { Earthquake, } \\
\text { China }\end{array}$ & $\begin{array}{l}\text { Qualitative study } N=25 \\
\text { (12- female; } 13- \\
\text { males) }\end{array}$ & QL-4 & $\begin{array}{l}\text { - Use of social support } \\
\text { networks } \\
\text { - Engaging in pleasurable } \\
\text { activities }\end{array}$ \\
\hline Wang et al. (2011) & Earthquake, China & $\begin{array}{l}\text { Qualitative study } N=25 \\
\text { (12- female; } 13- \\
\text { males) }\end{array}$ & QL-3 & $\begin{array}{l}\text { Use of social support } \\
\text { networks } \\
\text { - Providing support to } \\
\text { others }\end{array}$ \\
\hline $\begin{array}{l}\text { Zoleta-Nantes } \\
(2002)\end{array}$ & $\begin{array}{l}\text { Flood hazards, } \\
\text { Philippines }\end{array}$ & $\begin{array}{l}\text { Qualitative data } \\
\text { collected in phases in } 3 \\
\text { sessions about a year } \\
\text { apart. Participants } \\
\text { were } 45 \text { officials } \\
\text { (government \& NGOs, } \\
39 \text { urban poor, } 39 \\
\text { residents of wealthy } \\
\text { neighbourhoods, \& } \\
\text { nine street children }\end{array}$ & QL-2 & $\begin{array}{ll} & \text { Use of social support } \\
\text { network } \\
\text { - } & \text { Borrowing money } \\
\text { - } & \text { Diversification of income }\end{array}$ \\
\hline
\end{tabular}

*The MMAT score is the overall score for study based on the components of the study: Qualitative (QL) and Quantitative (QT) scores range from 1-4 and Mixed Methods (MM) from 0-3. 1(QL/QT) \& $0(\mathrm{MM})=25 \% ; 2(\mathrm{QL} / \mathrm{QT}) \& 1(\mathrm{MM})=50 \% ; 3(\mathrm{QL} / \mathrm{QT}) \& 2(\mathrm{MM})=75 \%$ and $4(\mathrm{QL} / \mathrm{QT}) \& 3(\mathrm{MM})=100 \%$ achievement of overall quality (Pluye, et al., 2011 


\section{University Library}

\section{- M M N E R VA A gateway to Melbourne's research publications}

Minerva Access is the Institutional Repository of The University of Melbourne

Author/s:

Krishna, RN;Majeed, S;Ronan, K;Alisic, E

Title:

Coping with Disasters While Living in Poverty: A Systematic Review

Date:

2018-01-01

Citation:

Krishna, R. N., Majeed, S., Ronan, K. \& Alisic, E. (2018). Coping with Disasters While Living in Poverty: A Systematic Review. JOURNAL OF LOSS \& TRAUMA, 23 (5), pp.419-438. https://doi.org/10.1080/15325024.2017.1415724.

Persistent Link:

http://hdl.handle.net/11343/274923 